\title{
MĀORI INDIGENEITY AND COMMODITY FETISHISM
}

\author{
Steven Webster ${ }^{1}$
}

\begin{abstract}
The Māori have survived at least three different sustained efforts to assimilate them since colonisation. I would argue that each time they have emerged as a substantially different culture as well as a different part of New Zealand society, and new efforts to assimilate them have had to confront the unpredictable results. To generalise, the first effort of assimilation was propelled by enlightened colonial arrogance, and finally by force; another effort started in the 1920 s and sought to help them be 'more Màori' by preserving their traditional culture. The most recent form of assimilation took shape in the 1980s but, facing what has come to be called indigeneity, became a kind of welcome (even a pow whiri) into the new world of neoliberal opportunities. In the 199os I traced some of the results since the 1920s, but I was only vaguely aware that this latest neoliberal phase of assimilation efforts had already begun. Fiona McCormack has, I think, best drawn together the critiques of this latest development, and furthermore appreciated its results as essentially unpredictable. In this essay I want to review some of her examples, and suggest that Marx's image of the fetishism of commodities better captures the ambiguous contradictions and unpredictabilities of the situations she describes.
\end{abstract}

Keywords: Māori indigeneity; political economy; commodity fetishism; ethnicity

\section{INTRODUCTION}

Probably beginning in the 1990 and developing in the last several years are commentaries on contemporary Māori indigeneity' in the context of the neoliberal form of governance that had been advancing rapidly through New Zealand society since the 1984 Labour government. Implicit in but contradictory to the issue of indigeneity is the much older issue of social or cultural assimilation; indeed, it can be argued that they are sometimes two sides of the 
same coin. Somewhat as the earlier effort to assimilate the Māori was coupled with 'cultural deficit theory' and the ideal to preserve traditional culture, the new effort couples the systematic commodification of society characteristic of neoliberal governance with indigeneity often backed by the Treaty of Waitangi.

In the 1990 o I was among a few who approached this dialectical problem from the direction of 'western' Marxism, but I remained naive compared to some of the current more radical directions. I had traced the rise of culturalist theories since the 1920 led by Māori and Pākehā anthropologists and administrators reconsidering the even longer-standing assimilationist policies that began with colonisation and continued until confronted by the Māori Renaissance in the 1970 and the re-recognition of the legal status of the Treaty of Waitangi in the 1980s (Webster 1998b, 73-102, 115; Ward 1999, 7-42). However, I did not get much beyond arguing that the shifting forms of culturalist idealism be seen in the context of a material history of conflict between changing social classes without resorting to Māori/Pākehā, two-worlds, or bicultural assumptions. In the 1990 os the most recent of these culturalist theories was a certain postmodernist 'ethnic piety' across departments at the University of Auckland, supposedly supporting but instead sublimating the Māori Renaissance. The closest I got to the current level of analysis was to point out (Webster 1998b, 256) that:

[...] the image of Māori culture developed in the Māori Renaissance [since the 1970s] often echoes the ideological functions of Māoritanga which emerged in the 1920s [the 'cultural deprivation' theory that 'the Māori are not Māori enough' - an ironic inversion of the assimilationist thesis (254)...]. These functions are furthermore sometimes consciously exploited by the state or other influential patrons of Māori culture to promote selected aspects of that culture while suppressing others and obscuring its history.

My own essay on Māori retribalisation under the fisheries settlements (Webster 2002) drew on drafts of Fiona McCormack's PhD thesis. Now, I hope I have more or less caught up with the new critical direction guided by McCormack's comprehensive essays since about 2010 on Māori indigeneity and claims settlements in the context of neoliberal government reforms. ${ }^{2}$

Here in the present essay, I want to explore the usefulness of adding the old Marxian critique of commodity fetishism to examples that McCormack has already analysed from both East Coast and West Coast Māori hapū, iwi, and marae. Marx's key insights into commodity fetishism have been kept in the forefront of anthropology by, among others, David Graeber of the London 
School of Economics, following a 1980s 'Chicago school' of value theorists building on Marx's labour theory of value in distinctively anthropological ways (Graeber 2013, 2015). My own interest in western Marxism and critical theory culminated with my belated appreciation of Eric Wolf's Europe and the People without History (1982). Although Wolf's later classic examination of cultural forces in Kwakiutl, Aztec, and Nazi political economy did not develop the fetishism thesis explicitly, he hoped to 'combine Marx's suggestion that the crucial nexus of structural power governing social labor will produce characteristic representations or misrepresentations in thought with an anthropological analysis of ideational complexes such as fetishism' (Wolf 1999: 35). Another of Wolf's insights that I think would benefit McCormack's analysis (but which I will not pursue here) is his perspective on 'uneven but combined development' of capitalism in the unique historical contexts of other cultures (Wolf 1982, 296-309; Webster 1998a, 23-31).

Marx's short section on 'The Fetishism of Commodities' in the introduction to Volume One of Capital is actually an ironic summary (playfully echoing Hegel's dialectic) of the preceding section on the relationship between use-value and exchange-value inherent in the form of commodities produced under capitalism (McLellan [ed] 1987, 421-443). This analysis of the commodity form is, in turn, central to his general theory of value as arising from human labour, whether in a capitalist or another mode of production. (This theory of value was later pursued anthropologically in terms of culture by Wolf, Sidney Mintz, William Roseberry and others and, more recently, by Graeber.) Marx defined 'use-value' as a specific quality arising from the intrinsic usefulness of a commodity in a specific social and historical context from which this sort of value is inseparable. On the other hand, 'exchange-value' is a quantity completely abstracted from the specifics of use-value and based entirely on exchange of a quantity of one commodity for a quantity of another. Exchange-value is entirely a quantitative relationship and thus varies independently of the use-value of a commodity. Marx credited himself with the discovery that this two-fold value of a commodity arises in capitalism from a two-fold form of labour: while individual labour in a specific social context produces the use-value of a commodity (gathering it from nature or producing it in manufacture), it is abstract labour-power in the general context of market exchange that produces the exchange-value of a commodity. The historical development of this twofold form of labour was the basis of capitalism.

It is important to understand that although Marx often portrayed exchangevalue as displacing use-value in the commodity form, he made it clear that this displacement is an illusory naturalisation or essentialisation of exchange-value 
that obscures the nevertheless subsisting use-value of the commodity, along with the historical development of the commodity form under capitalism. This illusion was the basis of his characterisation of the social and historical process as 'the fetishism of commodities', whereby the relations between the people who produce them take on the appearance of abstract exchange-values and, conversely, the relations between things, as commodities, take on the appearance of social relations between people. (TV commercials often vividly display this dialectic to us.) Marx's ironic use of Hegelian dialectic in his apparently detached economic explanation of this illusion was, of course, intended to dramatise the moral depravity of this aspect of the commodity form 'in a state of society in which the process of production has the mastery over man, instead of being controlled by him...' (McLellan [ed] 1987, 442). With similar irony, he also described the repeated re-creation and apparent disappearance of use-value in exchange-value in terms of 'living' and 'dead' or 'alienated' labour (McLellan [ed] 1987, 471; 508; 513).

Several decades later in 1923, Georg Lukács (1971, 83-4) argued that modern capitalism had extended commodity fetishism to 'the total outer and inner life of society. This potentially anthropological thesis was taken up in the historical materialist critique of surrealism and subsequently by the Frankfurt school of critical theory represented by Walter Benjamin, Theodor Adorno, Herbert Marcuse, and others (Webster 1990, 281-282).

In the following section I will review examples primarily from McCormack's most recent essay to lay out the way she has analysed the ambiguities between Māori indigeneity and assimilation to neoliberal governance while emphasising the unpredictability of the results. I hope to show that her analysis echoes the underlying two-fold character of both labour and the value it produces, remaining inherent in the commodity form despite the illusions of commodity fetishism. It is this particular ambivalence that is the unpredictable but irrepressible resource for Māori resistance against assimilation to a neoliberal form of indigeneity.

CONTEMPORARY MĀORI SOCIETY AND NEOLIBERAL GOVERNANCE

Fiona McCormack began her research in Māori fisheries claims and settlements in the 1990 s as a $\mathrm{PhD}$ candidate in social anthropology at University of Auckland and continued her field research especially among East Coast hapū and iwi while teaching at University of Hawaii. Since returning to New Zealand and teaching at Waikato University, she has extended her research to West Coast hapū and iwi. Her publications on the Māori have steadily broadened in 
using fisheries comparatively to exemplify and analyse the relation between neoliberal governance policies, property rights, commodities and gifts, indigenous claims and settlements, indigenisation processes, and environmental issues (McCormack 2010; 2011a, b, c; 2012a,b; 2013; 2015a,b).

Here I will focus on the most recent essay because it further extends these general issues to Māori grievance and settlement procedures, especially on marae as venues for Waitangi Tribunal and other comparable hearings. Her own position in this essay is summarised in this way:

[...] rather than constituting a liminal sphere of bicultural commensurability and restitutional justice, Tribunals are inextricably embedded in the construction of histories and the political economies of post-colonial societies. Conceptually, they are microcosms of the broader social struggle that characterizes contemporary indigenous engagement with neoliberal capitalism [....] Settlements, incongruously, can lead to new and arguabl[y] more permanent forms of loss, as the assets and resources returned are increasingly entangled with capitalist markets. New winners and losers have emerged and a set of grievances has been created for which no one is perceived to be accountable and for which no avenues for resolution are available. (McCormack 2015b, 6-7)

Citing Jane Kelsey (2014) and others, McCormack puts this global process of 'rolling back the [Keynesian] state' and 'rolling out' the uniquely neoliberal state in its New Zealand context (which in some ways antedated and exceeded parallel developments in the UK, USA, and even Chile) (McCormack 2015b, 17; Van Meijl 2013).

In my opinion the central value of McCormack's work is its moderation or avoidance of doctrine despite the often doctrinaire issues and, most importantly, her emphasis on what she even terms the 'messiness' (2015b:11) or unpredictability of these historical and cultural processes regardless of the unilateral global forces involved. At one point, she even hints that the 'precarity' or unpredictability of such 'decolonial practices' is a factor in what Guy Standing describes as the global emergence of a new class, the precariat (McCormack 2015b, 18; Standing 2011). However, (unlike my own theoretical inclinations) she does not let social class analysis displace cultural analysis. For her own especially anthropological insight McCormack credits William Roseberry's 'attention to the lack of coherence and system in culture, the ambiguous and contradictory nature of experience which is reflected in the production of a 
contradictory consciousness' in historically specific encounters that reproduce their own unique local social 'internalisation of the external' contradictions (McCormack 2015b, 5, 28; Roseberry 1989).

McCormack's theoretical, indeed, radical strength is at its best in this recent essay. My own special concern with commodity fetishism is implicitly raised here in her description of Roseberry's interest in the 'production of a contradictory consciousness' that through 'internalisation of the external' contradictions must be understood not psychologically but socially, as part of what Lukács pointed out had become 'the total outer and inner life of society'. From my perspective, it is precisely the ambivalence or precariousness of these internalised social contradictions and their inherently unpredictable social results that is best understood in terms of the two-fold nature of fetishised commodities. At least in some contexts of Māori indigeneity (and perhaps globally), this dynamic is also the source of the ambivalence between indigeneity and a new form of assimilation. However, before exploring these implications, I will review in McCormack's own more measured terms some of the specific New Zealand examples that she describes.

McCormack reviews a series of signal contradictions since the 1980 os that underlie claims and settlements since then: (i) the watershed date carefully drawn by government between acceptance of Māori claims regarding past loss of environmental resources and legislation progressively privatising control over these resources (McCormack 2015b, 8); (ii) the parallel operation of tribunal investigations of claims and government negotiation to co-opt the settlement of the same claim, furthermore coinciding with reduced resources for the tribunal (2015b, 10, 8-9); (iii) government requirements that claimants form a 'large natural group' and 'mandate' that has often shifted traditional authority from hapū to organisations that can claim to represent an iwi (2015b, 9); and (iv) managerial requirements for post-settlement assets that favour corporatisation of claimant social organisation, often iwi or their agencies $(2015 \mathrm{~b}, 10)$. I would only augment this list of underlying contradictory developments by pointing to the seabed and foreshore confrontation of 2004 and, with regard to private as well as Crown resources everywhere, their increasing vulnerability to offshore control.

Emphasising the nevertheless unpredictable results of such underlying contradictions, McCormack first describes the emergence of Waikato Tainui iwi or tribal 'muscle' acting in 2012 through a meatworkers' labour union, corporatised iwi administration, and the Parliament's Māori Party (McCormack 2015b, 13-15). In this way, this West Coast iwi forced a rare capitulation of Talleys, 
one of the largest privately owned agribusinesses in the country and main employer of iwi members, to give up in its bitter lockout dispute with the meatworkers and accept most of their demands.

With regard to the role of marae, McCormack emphasises that the increasingly varied use of these traditional ceremonial centres is not merely a bicultural backdrop to consultations, but is furthermore 'culturally and materially constitutive of a specific indigenous engagement with neoliberal governance', similarly in sometimes unpredictable ways $(2015 \mathrm{~b}, 18)$. She points out that what Mason Durie saw as 'The Decade of Māori Development' (1984-1994) (Durie 1998) began with the fourth Labour government's rapid institution of doctrinaire neoliberal policies. At that time and increasingly since, Māori aspirations for self-government began to be accommodated by devolving or 'outsourcing' social services to Māori at marae, including welfare, health, employment, and educational functions formerly supplied at government agencies for all citizens (McCormack 2015b, 19-20).

In addition to hosting hearings of claims to the Waitangi Tribunal, marae are favoured by other government agencies that are required to consult with hapu and iwi regarding a widening variety of environmental and resource extraction plans that may be subject to their treaty rights (McCormack 2015b, 18). Again with regard to the example of emerging contradictions in control over fisheries, McCormack describes how government legislation privatising fishing rights as ITQs (individually transferable quota) also disallowed traditional Māori reciprocity or exchange as well as the sale of fish, by assuming that these reflected 'pecuniary' interests contrary to customary Māori environmental as well as social morality $(2015 \mathrm{~b}, 18,27)$. Yet the result of this neoliberal primitivisation of Māori 'custom', as well as increasing joblessness, impoverishment, and demoralisation among Māori small fishers, is the unpredictable emergence of contradictory Māori discourses asserting traditional commercialism and, in one innovative East Coast iwi exploiting its privatised quota, even some 'traditional' fish processing, distribution, and discount retailing among cardcarrying iwi members (I will return to this example later).

As well as often receiving distributions of settlement assets, marae have become increasingly dependent financially on government subsidy for costs of hosting required consultations regarding natural resources (McCormack 2015b, 20). The increasingly commoditized and fungible relationship between the state and Māori' is extended by many marae to leasing of their facilities and even their ritual services to public or private functions. This is often facilitated through internet webpages, sometimes also gaining employment opportunities 
for the tangata whenua or marae community. However, social internalisation among Māori of such external engagements with neoliberalism have also produced 'tensions over old and new forms of authority, traditional accountability and legitimate economic activity' among the marae community (McCormack 2015b, 21).

To put such tensions between Māori in my proposed terms of the fetishism of commodities: depending on the participants' political economic or social class interests, the same 'fungibility' of abstract exchange-values of commoditised marae services can be either criticised or defended between its participants. The ambivalence of the situation is itself two-fold, both in the context of labour and production, and in the context of the values derived. The labour devoted to marae maintenance, hosting, or advertising can be identified as either personal production of traditional use-values or abstract production of exchange-values, because it may remain intrinsically both. Meanwhile, this ambivalent value can underwrite indigeneity as either authentic or modernised, and either as resisting or assimilated to neoliberal governance. The poles between which the tensions oscillate can be seen to have a common source in the illusions and realities of commodity fetishism. Finally, however, the social situation can become precarious: as the reality of one pole takes objective shape, the illusory nature of the other becomes apparent.

McCormack considers the possibility that this confluence of political economic changes on marae reinforces the social organisation of marae as 'houses' in Jeff Sissons' sense because they have become the legitimate centres for distribution of financial and social support (McCormack 2015b, 16-17, 20). I must demure from her suggestion here. It implies her acceptance of Sissons' thesis that marae, like medieval European 'houses', are only ideologically organised on the basis of common ancestral descent (that is, as hapū) while in reality since at least the 188 os they include a wide array of kin and non-kin who do not claim membership in the same hapu (Sissons 2010). As I argued against Sissons' thesis with regard to his own detailed data from Tuhoe, of course marae, as the usual meeting place of whānau (i.e., domestic groups living and working together), have always included spouses and whāngai tamariki (adopted children) as well as others who do not or cannot claim full membership in the same hapu that takes primary responsibility for the marae (Webster 2013, 2011). This does not mean that marae are controlled by 'houses' or whānau rather than hapū; to the contrary, I have argued that hapū were clearly the centre of Māori social organisation including marae in the $1840-50$ s, and have usually continued to be since then, often against the preferences of the government (Webster 1998a). 
Consistent with my own position on hapū, in earlier articles McCormack has emphasised their central role in East as well as West Coast kin groups in resistance or resentments against 'large natural' iwi organisations favoured by government as consultative partners and recipients of assets (McCormack 2011a, 2012b). In the present article she reports that two marae of the Tainui tribal (iwi) area whose kin groups (probably hapū asserting their independence as separate iwi within that West Coast area) disagreed with the conditions of the settlement are therefore excluded from receiving distributions of the settlement assets. McCormack also reports that one West Coast leader argues that 'the emphasis on marae, rather than the kin group (hapū or iwi), as the legitimate distributional space... undermin[es] Māori society as hapū, or people, based...' (2015b:20). Although these marae practices under neoliberal policies may indeed be weakening the paramount role of hapū in Mãori social organisation at the moment, this has been the intention of government policies at least since the 1840s, sometimes explicitly (Webster 1998a).

The main difference under neoliberal outsourcing of government services may be the illusion that marae and hapū are the same thing, resulting, as the hapu leader above suspected, from the confusion of hapu as a specific descent group of persons with marae as service locations. Indeed, this appears to be an example of the commodification of personhood. The confusion between a group of persons and a service location clearly reflects the ambivalence of commodity fetishism in its two-fold production by individual as well as abstract labour and the use-value as well as exchange-value that arises from this production. In any specific situation, this ambivalence can go either way. However, I have concluded that the long-established government inclination to weaken or marginalise hapu - precisely because their political potential remains intrinsically descent group based (unlike whānau and iwi) - has not so far been successful, at least in the long run since the 1840 os. Insofar as indigeneity has not been assimilated by neoliberal governance, it remains rooted in the structure of hapū.

McCormack reports further tensions between particular West Coast hapū and iwi organisations granted authority over them by government policies. The Tainui tribal hearings regarding the Aotea, Whaingaroa, and Kawhia harbours on the West Coast were limited to land losses, yet the 'elephant in the room' ([quoted from] research participant) is the inshore fisheries of these harbours (McCormack 2015b, 24-5). These fisheries' claims have been precluded from formal consideration because the 1992 fisheries settlement had been accepted by the favoured iwi organisation of Waikato Tainui as a 'full and final' settlement of all Waikato Tainui fisheries claims. As is generally the case throughout New Zealand, the 1992 settlement co-opted Māori customary inshore fishery 
rights judged to be 'pecuniary' along with the recognition of Māori commercial rights - at the same time privatising both as ITQs leasable as internationally fungible commodity exchange-values.

In addition to the 'internal struggles' on the West Coast between iwi authorities favoured by government and hapū resisting this authority as aspiring iwi, McCormack also emphasises 'emergent class relations and contestations over the unequal distribution of the benefits' of these fisheries settlements $(2015 \mathrm{~b}, 25)$. Although she does not go into detail in this essay, these emergent differences of social class between Māori had been aggravated by loss of customary fisheries rights among many of the coastal hapū while the indirect benefits accrued to corporatised iwi organisations and their (recognised) members. With specific regard to emergent class relations among tangata whenua, McCormack earlier described at length a parallel situation in a Māori fishing community in Northland about 100 kilometers north of Auckland (2010, 28-32).

Palpable in McCormack's account of West Coast Māori fisheries is her personal offense at this 'silencing' of claims, not only of the coastal harbour Tainui iwi (or hapū) control over their own food and livelihood, but also of their identity as sea people as opposed to the inland Waikato Tainui iwi's identification with the Waikato river' and the 1860 os land confiscations.

It is the incongruity of living by the sea, crippling rates of local unemployment, the inability to generate an income from an ancestral resource, fishing practices and policies that are perceived to be culturally irreverent and environmentally destructive that most frustrates local Māori. (2015b, 24)

Ironically, the Waikato Tainui iwi corporation whose 1992 commercial fisheries settlement has been obstructing any consideration of the West Coast harbours' customary inshore fisheries claims may be closely associated with the Waikato-Tainui Fisheries Ltd that helped break Talleys Group Holdings' lockout of the meatworkers union in 2012, described above. McCormack mentions that the similar bargaining power of this iwi fisheries corporation was quietly 'on the table', backing corporate Māori control of $40 \%$ of Talleys' beef supply (2015b:14). Rubbing salt into the wounds of the Tainui harbours' sea people, the loss of their inshore fisheries rights might in this way have reinforced the display of corporatised iwi 'muscle' and elite Māori leadership of Waikato Tainui in their confrontation with Talleys.

Put in terms of the ambivalent illusions of fetishised commodities, that sur- 
prising momentary reversal of commoditised iwi labour and meat against the corporate personification of neoliberal state power in 'Talleys' was only the surface spectacle. It contained within it a further reversal backed by legislation, but this one was the earlier expropriation in privatised exchange-value by the same iwi of the whole history of personal labour, inshore fish, and use-values of their own harbour people.

INDIGENEITY, ASSIMILATION, AND THE AMBIVALENCES OF COMMODITY FETISHISM

In what way might other specific local 'encounters' or contradictions described by McCormack be clarified by understanding them in terms of the shifting social illusions of commodity fetishism? More importantly, can such an understanding display the intrinsic historical unpredictability that McCormack claims for these contradictions? Her own example of an attempt to ease tensions between hapū, iwi authorities, and the neoliberal policies favouring the latter may furnish a lead. As mentioned earlier, these tensions had been met on the East Coast by Ngāti Porou's iwi-sponsored 'attempts to Maorify the economy' by establishing a fisheries 'processing unit through which fish are distributed to marae for ceremonial events' (McCormack 2015b:27). More recently, 'the iwi has also begun to operate a mobile fish truck, where prices are comparatively reasonable and a popular discount card is available for $i w i$ members.'

Can these specific innovations be seen in terms of the commodity form: appearing socially on the one hand as ordinary persons expending personal labour in the production of intrinsic use-values but, on the other hand, appearing not as persons but as abstract labour-power, paid by the hour or the week, while producing exchange-values between commodities - commodities which include the producers, distributors, and consumers themselves? To paraphrase Marx, how might these fish and their producers turnabout, appearing in one context as a process of commodity production that has 'mastery over man' as well as fish, but in the next context appear instead as production of fish and social relations over which ordinary persons have maintained control? Finally, can we see this ambivalence in terms of indigeneity and assimilation - even ironically as 'two sides of the same coin'?

Moreover, if we are to accept Lukács' understanding of this dialectic as replicated in 'the total outer and inner life of society', how can this very local development be seen as a microcosm of neoliberalised East Coast, furthermore in a globalised New Zealand? Finally, if McCormack is right in emphasising 
the essential unpredictability of this local development between fish and the production of value, one must be concerned as well about which momentary illusion of the commodity form will gain the upper hand in the course of this local material history and its national and global correlates. And, more generally, how does this outcome bear on the relation between indigeneity and assimilation? Although these further issues necessarily remain implicit, I will set them aside in hope that others might follow them up.

McCormack does not describe in detail either the West or East Coast encounters but, augmented by details of the closely parallel situation in a Northland fishing community that she reported in 2010 as I mentioned above, I can add some imaginary details to the vivid contradictions she describes.

If the East Coast Ngati Porou iwi authority has worked out ways to 'Maorify' their fish processing, distribution, and discount cards to marae as 'customary' redistributions or koha (gifts) despite the statutory restrictions on 'pecuniary' exchange between Māori, this might be seen by either (or both) the iwi authority and gatherings at marae as an effective turnabout on neoliberal policy assumptions. Even if these initiatives have to be treated 'on the books' as commercial fishery transactions by the corporate iwi arms of Ngati Porou, they might be seen by both the iwi suppliers and the marae recipients as successful Māori 'bait-and-switch' subterfuges or scams that one-up a presumed neoliberal conspiracy of the government. In a similar spirit, local government agents (Pākehā or Māori) may turn a blind eye.

From the point of view of commodity fetishism, the social illusion of commodified fish may be breached by the reality of fresh-caught fish - or vice versa. From one point of view, this situation might be seen as the abstract labour-power of hourly fishers and other employees of the iwi's fish-processing plant and mobile fish truck, producing and distributing only 'red herring' for gatherings on the marae; from a contradictory point of view, this situation might come to be seen instead as iwi fishers and plant workers who, like the workers and guests being feasted on the marae, are through their personal labour producing and consuming fresh use-values that feel and smell different in the nets, the processing plant, and the truck, and truly smell and taste freshly caught when purchased with the discount card, cooked, and eaten on the marae or at home. Perhaps in this way, the hapū has actually gained the upper hand against the corporate iwi. Yet the illusion of corporate control may also come to be seen as the reality, and the reality of personal labour and fresh fish be revealed as illusion. All it might take is a rise in prices, or a day's delay in the fish truck, or a rising sense that the iwi's initiatives are patronising or in 
bad faith, at either the marae or the fish truck or the plant, and the red herring becomes the reality while the fresh, locally caught feel, smell, and taste of fish becomes the bitter illusion.

Of course such ethnographic possibilities must not lose sight of the brute fact that while such a dialectic of social illusions may be creative politics or even the fun of switch-and-bait tactics at the marae, the plant, or the government agencies involved, in the longer run of this local material history it is a matter of real hunger, real jobs, and the real dignity of control over labour and production - and very real differences in the political economic power to achieve or deny these values as well as control the form of production. The precarious difference between indigeneity and assimilation may also lie in the balance.

Back on the West Coast with the Tainui iwi, similar turnabout ironies might be recognised in the inland iwi business boardrooms as well as among the harbour hapu and marae. McCormack's introductory description of Waitangi Tribunal hearings on one such marae, with a background of frustrated groans or approving applause as well as snores and children's play, is vivid enough. We can imagine that the silence of legally precluded claims to the harbour and inshore fisheries is still the elephant (or moa) in the meetinghouse.

Because only claims to land can be formally raised, the particular issue before the hearing, say, is a sacred site, a supposed urupā (cemetery) or at least the burial site of one or another ancestral hapū rangatira, on land lost during WWI under the public works act. Because the piece of land in question eventually became private property, everyone knows that the only available reparation is a possible trade-off with nearby public land along the coast offering a small but prime building site. The exchange-value of such a trade-off is clear enough as a source of needed income to maintain nearby marae; although the resting-place of the ancestor would be left out in the cold it could continue to be visited with permission of the landholder, and the ancestor's name would continue to be spoken of in gatherings at the marae.

Although the lawyers and the judge make half-hearted attempts to return discussion to land issues over which the Tribunal has jurisdiction, one local witness after another dramatically describes the ancestor, the burial site, and even the prime building site in terms of the productivity of the local inshore fisheries: the ancestors were buried with their fishing tools or greenstone images of them; a derelict fishing waka (canoe) lies buried nearby under the ruins of his home; the building site is daily traversed by enthusiastic spear-fishermen as well as surfers; mothers sit forlornly viewing tidal flats that used to feed 
their whaanau; middens of pāua shells and shark teeth abound along the high ground above the building site; one can still taste the flavour and smell the aromas of the hāngi in which they were cooked decades ago. The audience of sea people begins to stir. Hungry rumblings bemoan lost fishing jobs.

This subversive litany continues until a representative of the corporate Waikato Tainui iwi stands and speaks out indignantly to remind the locals that many of their inland relatives owe their jobs in the meat-processing plants to the bargaining power of Waikato-Tainui Fisheries Ltd in the settlement with Talleys Group Holdings only a few years ago. He adds angrily that the iwi fisheries company also subsidises their marae with cash from the fish. But then Huka, a locally well-known imposing young woman stands up in the audience interrupting him, and muffled groans are heard all around her. Her waikauri (tatooed) face quivers. She begins quietly by stating that this marae receives neither fish nor their lousy subsidy, adding in rising volume that this is because the real iwi here on the harbour had told his corporate iwi in the city that they could stuff their arrangement with the government right up their tero! Lowering her voice in disdain, she adds that their fisheries company didn't even know how to fish and instead had leased the whole Waikato Tainui fisheries quota - along with all the inshore quota of the harbours over which they had no mana at all - the very livelihood of her parents and their ancestors for generations! - leased to Japanese ships with Taiwanese crews whom the real fishers of these harbours had never even met...! instead, here they were hosting him, a mere corporate clerk, on their marae. Here she pauses to turn her backside toward the speaker, clearly threatening a whakapohane. The judge intervenes hastily to call an adjournment; Huka’s whānau kaumātua (elders) hurriedly stand up all around her so her display cannot be seen, and heave sighs of relief.

\section{CONCLUSION}

Hidden but at the same time in plain view in these exchanges are various use-values passing as exchange-values and vice versa, from the ancestors buried with their fishing tools to the middens still rich with the smells of fresh seafood hangi, each coupled implicitly with labour producing that value as ambivalently either abstract or personal, 'indigenous' or 'neoliberal', Māori or Pākehā. Although disenfranchised from legitimate access to their own inshore fisheries, the people of the marae continue to get some of it fresh late at night or 'under the table' in the usual Kiwi fashion; relatives with good inland jobs in the iwi agencies, or inland meat-workers union members thankful for their jobs, bring their launches to the harbour for weekend fishing expeditions but are careful to quietly distribute part of their recreational catch - just as though 
it were customary catch - among related hapū members and even to marae; meanwhile, local fisheries officers either get some of it for themselves or conspire enthusiastically to define such koha gifts as having a pecuniary interest and triumphantly secure a conviction. Thus can a sea person, Māori or Pākehā, be brought low. And in this way indigeneity and assimilation may be two sides of the same false coin.

Whichever sort of local labour it really is, and whichever sort of value it really produced, is shown among neighbors or relatives for all to see in the inequalities of political economic power it produced, along with the struggle for indigeneity, the schisms between iwi and hapu, and the social class hostilities within hapū. All the contradictions in this labour and irreconcilable kinds of value it produces continue to lie restive in a material history made up in part by a drama such as the marae confrontation described above. Every child who witnesses that drama will be capable of unfolding it someday, as Walter Benjamin said (Webster 1990, 284), like a child unfolds a paper boat in the palm of his or her hand, and so finally comes to understand it. The fullness of that moment has already passed into that material history in all its unpredictable promise as well as bitterness, wound up tightly in a pōkaikaha (quandary) that awaits its future.

\section{NOTES}

1 Steven Webster immigrated with his family from the USA in 1972 and taught courses in social anthropology and Maori studies at the University of Auckland until retiring in 1998. He continues there as an Honorary Research Fellow. His PhD thesis from University of Washington was on kinship, ecology, and ethnicity in the Peruvian Andes, but in New Zealand he took up research among Maori in the Urewera and the university. His courses developed from kinship, ethos and worldview, ethnicity, history of anthropology, and Maori land history in colonial New Zealand, to political economic critique of ideologies. Since retiring he completed research for the Waitangi Tribunal on the Urewera District Native Reserve, Crown purchase campaign, and Consolidation Scheme 1894-1926, and continues ethnohistorical research on that era.

Email: swebster2@yahoo.com

2 Fiona McCormack's response to Steven Webster's article is the next article. 
REFERENCES:

Durie, Mason. 1998. Te Mana, Te Kāwanatanga: The Politics of Maori Self-Determination. Auckland: Oxford University Press.

Graeber, D. 2013. 'It is value that brings universes into being'. HAU: Journal of Ethnographic Theory 3 (2):219-43.

- 2015. 'Radical alterity is just another way of saying 'reality': A reply to Eduardo Viveiros de Castro', HAU: Journal of Ethnographic Theory, 5(2):1-41.

Kelsey, J. 1996. Economic Fundamentalism: The New Zealand Experiment - A World Model! UK: Pluto Press.

Lukács, Georg. 1971 [1922]. History and Class Consciousness: Studies in Marxist Dialectics. Translated by R. Livingstone. Cambridge, Mass.: M.I.T. Press.

McLellan, D. (ed). 1987. Karl Marx; Selected Writings. Oxford: Oxford University Press.

McCormack, F. 2010. 'Fish is my daily bread: owning and transacting in Maori fisheries'. Anthropological Forum 20 (1):19-39.

- 2011a. 'Levels of indigeneity: the Māori and neoliberalism', Journal of the Royal Anthropological Institute (N.S.) 17:281-300.

- 2011b. 'Rāhui: a blunting of teeth', Journal of the Polynesian Society 120 (1): $43-55$.

_. n.d. (2011c). 'Quota systems: repositioning value in New Zealand, Icelandic and Irish fisheries', (draft supplied by author).

- 2012a. 'The reconstitution of property relations in New Zealand fisheries.' Anthropological Quarterly 85(1):171-201

_. 2012b. 'Indigeneity as process: Māori claims and neoliberalism'. Social Identities $18(4): 417-434$.

- 2013. 'Commodities and gifts in New Zealand and Hawaiian fisheries'. In Engaging with Capitalism: Cases from Oceania, edited by F. McCormack and K.Barclay. Research in Economic Anthropology 33: 53-81. United King- 
dom: Emerald Group Publishing. doi:http://dx.doi.org/10.1108/So19o1281 (2013)0000033005

- 2015a. 'Mauss, interestedness, and disinterestedness: Hawaiian and Maori Fisheries'. Anthropological Forum 1-21. doi:http://dx.doi.org/10.108o/oo66 4677.2015.1044941

. 2015b. 'Indigenous claims: hearings, settlements and neoliberal silencing.' Paper presented at 4oth annual conference of the AsAAnz (Association of Social Anthropologists of Aotearoa New Zealand), 25-27 November 2015, Massey University, Palmerston North (to be published in PoLAR, spring 2017).

Roseberry, W. 1989. Anthropologies and Histories; Essays in Culture, History, and Political Economy. New Brunswick: Rutgers University Press.

Sissons, J. 2010. 'Building a House Society: The reorganization of Maori communities around meeting houses. Journal of the Royal Anthropological Institute (N.S.) 16:372-86.

Standing, G. 2011. The Precariat: The New Dangerous Class. London and Chicago: Bloomsbury Academic Press.

Van Meijl, T. 2013. 'Ownership and distribution in the settlement of Maori grievances: balancing historical and social justice between classes'. In Engaging with Capitalism: Cases from Oceania, edited by F. McCormack and K. Barclay, Research in Economic Anthropology 29-52. United Kingdom: Emerald Publishing. doi:http://dx.doi.org/10.1108/So190-1281(2013)0000033005

Ward, A. 1999. An Unsettled History; Treaty Claims in New Zealand Today. Wellington, New Zealand: Bridget Williams Books.

Webster, S. 1990. 'The Historical Materialist Critique of Surrealism and Postmodernist Ethnographic Forms'. In Modernist Anthropology: From Fieldwork to Text, edited by M. Manganaro, 266-99. Princeton, New Jersey: Princeton University Press.

-1998a. 'Maori hapuu as a whole way of struggle; 1840 - -50 s before the Land wars. Oceania 69 (1): 4-35. 1998b. Patrons of Maori Culture: Power, Theory, and Ideology in the Maori 
Renaissance. Dunedin, New Zealand: The University of Otago Press.

-2002. 'Maori retribalization and treaty rights to the New Zealand fisheries.' The Contemporary Pacific 14 (2):341-376.

- 2011. 'Do Maori know what a hapuu is?' Journal of the Royal Anthropological Institute, (N.S.) 17:622-627.

- 2013. 'Are Maori hapū 'houses'? Are whakapapa 'strategic improvisations? The ethnohistorical evidence from Ngai Tuuhoe'. Sites (new series) 10 (1):3050 .

Wolf, E.R. 1982. Europe and the People without History. Berkeley: University of California Press.

- 1999. Envisioning Power: Ideologies of Dominance and Crisis. Berkeley: University of California Press. 